\title{
Kwestionariusz do badania relacji trener-zawodnik (CART-Q): polska adaptacja (PICART-Q)
}

\author{
Anna Michalak ${ }^{1}$ \\ anna.michalak@wyspa.bydgoszcz.pl \\ Artur Poczwardowski \\ apoczwar@du.edu \\ University of Denver (USA)
}

\begin{abstract}
W pracy dokonano polskiej adaptacji kulturowo-językowej wersji anglojęzycznej kwestionariusza do badania relacji trener-zawodnik: The Coach AthleteRelationship Questionnaire (CART-Q; Jowett i Ntoumanis, 2004). Nowo powstałe narzędzie (PICART-Q) wykorzystano w badaniu polskich zawodników $(\mathrm{N}=97)$ i trenerów $(\mathrm{N}=65)$. Miało ono na celu zbadanie trafności teoretycznej i kryterialnej narzędzia oraz jego rzetelności. Konfirmacyjna analiza czynnikowa nie potwierdziła trafności teoretycznej narzędzia. Przeprowadzono eksploracyjną analizę czynnikową metodą głównych składowych, która wykazała istnienie jednego ogólnego czynnika - relacja trener-zawodnik.
\end{abstract}

\section{Wprowadzenie teoretyczne}

Związek trener-zawodnik ma poważny wpływ na jakość doświadczeń w sporcie oraz wynik sportowy (Poczwardowski, Barott i Jowett, 2006). Jowett i współpracownicy (np. Jowett, 2003; Jowett i Cockerill, 2003; Jowett i Meek, 2000) postawili sobie za zadanie stworzenie modelu teoretycznego, który usystematyzowałby zagadnienia związane ze związkiem trener-zawodnik $\mathrm{z}$ perspektywy relacji. Zaowocowało to stworzeniem kwestionariusza do badania relacji trener-zawodnik: The Coach-Athlete Relationship Questionnaire (CART-Q) i The Greek Coach-Athlete Relationship Questionnaire (GrCART-Q; Jowett i Ntoumanis, 2003, 2004). CART-Q zawiera trzy podskale: bliskość (closeness), komplementarność (complementarity) oraz zaangażowanie (commitment), zwięźle nazwane modelem 3C.

\footnotetext{
${ }^{1}$ Raport $\mathrm{z}$ badania został napisany na podstawie pracy magisterskiej pt. „Polska adaptacja kwestionariusza do badania relacji trener-zawodnik (PICART-Q)", napisanej w Szkole Wyższej Psychologii Społecznej w Warszawie pod kierunkiem dr Artura Poczwardowskiego i recenzowanej przez dr Dariusza Parzelskiego.
} 
Pojęcie bliskości jest opisywane jako emocjonalna współzależność, uczucie emocjonalnej bliskości, która zawiera w sobie poczucie, że ktoś o nas dba, że jesteśmy lubiani, szanowani i cenieni, a także, że możemy sobie wzajemnie ufać. Świadczy też o stabilności relacji i satysfakcji jej członków. Komplementarność to pojęcie zakładające, że każde zachowanie interpersonalne wywołuje odpowiedź w formie zachowania drugiej osoby. Relacja trener-zawodnik opiera się na ciągłej wymianie działań. Wysiłki trenera nie mają żadnego znaczenia jeśli zawodnik nie odpowiada na nie swoim zachowaniem. Zaangażowanie wiąże się z tym, że osoby znajdujące się w relacji są od siebie dosłownie zależne i potrzebują swojego związku, który przynosi im pożądane rezultaty. Zaangażowanie zakłada nastawienie na długotrwałość relacji oraz psychologiczne przywiązanie, które wiąże się między innymi z tym, że rezygnacja ze swoich korzyści na rzecz partnera nie jest uważana za kosztowną. Intencją zawodnika i trenera jest utrzymanie relacji w celu maksymalizacji osiąganych rezultatów.

\section{CART-Q: charakterystyka oryginalnego narzędzia}

CART-Q składa się z 11 stwierdzeń. Trzy z nich mierzą zaangażowanie, cztery bliskość i kolejne cztery komplementarność. Jest to narzędzie samoopisowe; zadaniem osoby badanej jest wskazanie na ile zgadza się bądź nie zgadza się z danym stwierdzeniem. Pozycje kwestionariusza oceniane są na siedmiopunktowej skali, gdzie 1 oznacza "zdecydowanie się nie zgadzam" (strongly disagree), 4 jako "umiarkowanie" (moderately) i 7 jako "zdecydowanie się zgadzam" (strongly agree). Analiza indeksów dopasowania wykazały zasadność modelu wyodrębnienia trzech osobnych czynników pierwszego rzędu (podskale), które jednak ujęte są w jeden ogólny wymiar rzędu wyższego (relacja trenerzawodnik).

W celu zbadania trafności kryterialnej narzędzia wykorzystano zmienną: poziom satysfakcji interpersonalnej. Trafność zbadano osobno dla modelu zakładającego istnienie jednego czynnika wyższego rzędu oraz dla modelu drugiego - sugerującego trzy czynniki niższego rzędu. Pierwszy model uzyskał bardzo wysoki współczynnik trafności diagnostycznej $(\beta=0,89 ; p<0,01)$, drugi natomiast wykazał, że satysfakcja interpersonalna mogła być prognozowana przez bliskość $(\beta=0,37 ; p<0,01)$ i komplementarność $(\beta=0,36 ; p<0,01)$, ale nie przez zaangażowanie $(\beta=0,20 ; p>0,05)$. 
Także rzetelność kwestionariusza została zmierzona osobno dla wspomnianych wyżej dwóch modeli. Dla modelu jednoczynnikowego współczynnik $\alpha$-Cronbacha wyniósł $\alpha=0,93$, a dla modelu trzech czynników odpowiednio dla zaangażowania $\alpha=0,82$, dla bliskości $\alpha=0,87$ i dla komplementarności $\alpha=0,88$. Wynik dla obu modeli wskazują na rzetelność narzędzia.

\section{Badania wlasne}

Celem tej pracy jest dokonanie językowo-kulturowej adaptacji kwestionariusza do badania relacji trener-zawodnik CART-Q z języka angielskiego na język polski oraz zbadanie podstawowych właściwości psychometrycznych nowopowstałego narzędzia, któremu nadano nazwę PICART-Q.

\section{Metoda}

W badaniu wykorzystano powstałą polską wersję kwestionariusza do badania relacji trener-zawodnik (PICART-Q). Do kwestionariusza dodano dwie dodatkowe pozycje mierzące satysfakcję interpersonalną, by zbadać trafność kryterialną narzędzia. Pozycje kwestionariusza mierzono na siedmiopunktowej skali, gdzie 1 oznacza ,zdecydowanie się nie zgadzam”, 4 ,umiarkowanie”, a 7 ,zdecydowanie się zgadzam”. Natomiast pozycje mierzące satysfakcję interpersonalną mierzono na siedmiopunktowej skali, gdzie 1 oznacza „nie jestem wcale usatysfakcjonowany”, 4 ,umiarkowanie”, a 7 ,jestem zupełnie usatysfakcjonowany". Kwestionariusz składa się z dwóch wersji, osobnej dla zawodnika i trenera (Załącznik 1).

\section{Przebieg badań}

W pierwszym etapie tworzenia polskiej wersji PICART-Q zastosowano metodę thumaczenia zwrotnego (back-translation) wykorzystując procedurę translacji oraz transkrypcji (Drwal, 1995). Dwie osoby władające oboma językami oraz zaznajomione $\mathrm{z}$ modelem 3C, dokonały niezależnych translacji kwestionariusza. Powstałe wersje polskie zostały następnie przetłumaczone zwrotnie na język oryginalny (tj. angielski) przez niezależnych tłumaczy-filologów. Dodatkowo trzecia osoba dokonała transkrypcji kwestionariusza na język polski. Wszystkie trzy wersje zostały przeanalizowane podczas 
grupowej konsultacji. Wybrano jedną wersję kwestionariusza, którą następnie skonsultowano z dwoma filologami polskimi pod kątem poprawności językowej. Zasugerowane przez nich drobne poprawki zostały uwzględnione.

W badaniu wzięło udział 97 zawodników i 65 trenerów $(n=162)$. Spośród wszystkich osób 122 to mężczyźni (66 zawodników i 56 trenerów), a 40 to kobiety (31 zawodniczek i 9 trenerek). Średni wiek zawodników to 21,6 lat ( $\mathrm{SD}=3,31)$, a średni wiek trenerów to 43,5 lat $(\mathrm{SD}=13,17)$. Wśród uczestników badania największą grupę stanowili przedstawiciele sportów zespołowych (54,9\%; np. piłka nożna); mniejszą grupą były osoby związane ze sportami indywidualnymi (34\%; np. lekkoatletyka); wyróżniono także formę mieszaną $(11,1 \%$; tj. wioślarstwo). Uczestnicy badania reprezentowali różne poziomy sportowe: 0,6 \% poziom rekreacyjny, 19,1\% akademicki, 32,1\% klubowy, 24,7\% krajowy, a $22,8 \%$ poziom międzynarodowy. Jedna osoba nie wskazała poziomu sportowego. Większość osób badanych (95,7\%) była w typowej relacji trener-zawodnik; 3,7\% w relacji rodzicielskiej, a $0,6 \% \mathrm{w}$ relacji małżeńskiej. Osoby będące w rozwiniętej relacji trenerzawodnik stanowiły 59,3\% badanych (relacje trwające od 6 miesięcy do 3 lat), a osoby będące w relacji ugruntowanej 40,7\% (relacje trwające od 3 lat i 2 miesięcy do 16 lat).

Uzyskano zgodę autorki oryginału na tłumaczenie oraz adaptację kulturową oraz zgodę Komisji Etycznej na przeprowadzenie badania. Dane od wszystkich zawodników i części trenerów zbierane były podczas bezpośrednich spotkań z uczestnikami badania. Pozostała część zainteresowanych trenerów otrzymywała pakiety $\mathrm{z}$ prośbą o samodzielne wypełnienie i przesłanie ich drogą pocztową. Spośród wszystkich kwestionariuszy 132 zebrano osobiście (w tym od 35 trenerów). Drogą pocztową do wypełnienia zostało przekazanych 67 kwestionariuszy; wypełnione kwestionariusze otrzymano od 30 trenerów. Wszyscy uczestnicy badania otrzymywali: (1) formularz zgody na udział w badaniu przy dobrowolności wzięcia udziału w badaniu i poufności uzyskanych informacji; (2) kwestionariusz oraz (3) zaadresowaną kopertę ze znaczkiem zwrotnym (tylko w przypadku, gdy kwestionariusz miał być odesłany drogą pocztową).

\section{Uzyskane wyniki}

W Tabeli 1 zawarte są średnie, odchylenia standardowe, skośność i kurtoza dla 11 pozycji kwestionariusza. Większość (10 z 11) średnich jest relatywnie wysoka (powyżej 5 na siedmiopunktowej skali). Najniższa średnia wynosi 4,48. Wartości skośności wahają się 
od $-2,88$ do $-0,38$, a kurtozy od $-0,89$ do 9,70 wskazując, że zmienne nie mają rozkładu normalnego.

Tabela 1. Statystyki opisowe dla PICART-Q

\begin{tabular}{lllll}
\hline Numer pozycji & M & SD & Skośność & Kurtoza \\
\hline Bliskość & & & & \\
3 & 5,77 & 1,30 & $-1,45$ & 2,12 \\
5 & 5,62 & 1,42 & $-1,27$ & 1,34 \\
8 & 6,50 & 1,00 & $-2,88$ & 9,70 \\
9 & 6,25 & 1,14 & $-1,82$ & 3,19 \\
\hline Zaangażowanie & & & & \\
1 & 4,48 & 1,49 & $-0,38$ & $-0,16$ \\
2 & 5,12 & 1,52 & $-0,45$ & $-0,89$ \\
6 & 5,10 & 1,61 & $-0,82$ & $-0,01$ \\
\hline Komplementarność & & & & \\
4 & 5,94 & 1,24 & $-1,17$ & 0,64 \\
7 & 5,88 & 1,22 & $-1,22$ & 0,91 \\
10 & 6,21 & 1,04 & $-1,53$ & 2,29 \\
11 & 6,06 & 1,16 & $-1,40$ & 1,52 \\
\hline
\end{tabular}

Analiza zgodności wewnętrznej wykazała wysokie wartości współczynnika $\alpha$-Cronbacha w przypadku wszystkich skal PICART (>0,70; Nunnally i Bernstein, 1994): dla bliskości $\alpha=0,86$, dla zaangażowania $\alpha=0,79$ a dla komplementarności $\alpha=0,85$; oraz dla jednego ogólnego konstruktu relacja trener-zawodnik zawierającego w sobie wszystkie pozycje kwestionariusza $\alpha=0,92$.

Do zbadania trafności kryterialnej kwestionariusza użyto zmiennej „satysfakcja interpersonalna". Stanowi ona uśrednienie dwóch jej wskaźników (pozycje \#12 i \#13, Załącznik 1). Korelacja między tymi pozycjami: $r(159)=0,65 ; p<0,001$. Trafność diagnostyczną kwestionariusza PICART-Q sprawdzono przeprowadzając korelacje Pearsona między kolejnymi pozycjami a zmienną kryterialną, między wynikami w poszczególnych skalach a zmienną kryterialną oraz między wynikiem ogólnym a zmienną kryterialną (Tabela 2). Wszystkie korelacje ze zmienną kryterialną okazały się istotne statystycznie. Korelacje trzech pozycji wykazały umiarkowaną siłę związku $(0,4$ do $0,6)$, a pozostałe to korelacje silne (0,6 i więcej). Trafność diagnostyczna została zachowana. 
Tabela 2. Korelacje między pozycjami i skalami a zmienną kryterialną.

\begin{tabular}{ll}
\hline Numer pozycji & Współczynnik korelacji Pearsona \\
\hline Bliskość & 0,77 \\
3 & 0,70 \\
5 & 0,73 \\
8 & 0,56 \\
9 & 0,61 \\
\hline Zaangażowanie & 0,70 \\
1 & 0,52 \\
2 & 0,60 \\
6 & 0,64 \\
\hline Komplementarność & 0,77 \\
4 & 0,71 \\
7 & 0,65 \\
10 & 0,46 \\
11 & 0,72 \\
\hline Wynik ogólny & 0,82
\end{tabular}

Wszystkie korelacje istotne na poziomie $\mathrm{p}<0,001$.

Badając trafność teoretyczną, w pierwszej kolejności przeprowadzono analizę struktury wewnętrznej testu aby zbadać na ile kwestionariusz P1CART-Q jest homogenicznym narzędziem jednego konstruktu teoretycznego. Tabela 3 przedstawia współczynniki korelacji między poszczególnymi pozycjami testu a ogólnymi wynikami w całym teście oraz w poszczególnych skalach. Wszystkie pozycje skorelowane są z wynikami ogólnymi kwestionariusza, ale także z każdą ze skal. Zauważyć można, że najwyższe współczynniki korelacji pozycje osiągają ze skalą, do której należą. Wyniki te wskazują na zgodność wewnętrzną całego kwestionariusza jak i jego poszczególnych skal.

W kolejnym kroku przeprowadzono analizę macierzy korelacji Pearsona między wszystkimi pozycjami PICART-Q. Wykazały one istotne statystycznie korelacje między wszystkimi pozycjami kwestionariusza. Widać wyraźnie, że pozycje są ze sobą powiązane nie tylko w obrębie przyjętych skal teoretycznych. Powstaje więc przypuszczenie, że mogą się one łączyć w inne czynniki niż te wskazane w modelu 3C. 
Tabela 3. Analiza struktury wewnętrznej

\begin{tabular}{lllll}
\hline Numer pozycji & Wynik ogólny & Bliskość & Zaangażowanie & Komplementarność \\
\hline Bliskość & & & & \\
3 & 0,82 & 0,86 & 0,67 & 0,70 \\
5 & 0,83 & 0,88 & 0,65 & 0,72 \\
8 & 0,69 & 0,79 & 0,45 & 0,63 \\
9 & 0,82 & 0,85 & 0,62 & 0,76 \\
\hline Zaangażowanie & & & & \\
1 & 0,68 & 0,56 & 0,85 & 0,45 \\
2 & 0,72 & 0,56 & 0,85 & 0,56 \\
6 & 0,79 & 0,67 & 0,83 & 0,65 \\
\hline Komplementarność & & & & 0,82 \\
4 & 0,75 & 0,66 & 0,56 & 0,87 \\
7 & 0,84 & 0,78 & 0,64 & 0,75 \\
10 & 0,63 & 0,52 & 0,44 & 0,86 \\
11 & 0,80 & 0,78 & 0,54 & \\
\hline
\end{tabular}

Wszystkie korelacje istotne na poziomie $\mathrm{p}<0,001$

W celu dokładniejszej analizy przeprowadzono konfirmacyjną analizę czynnikową (Confirmatory Factor Analysis - CFA), za pomocą której sprawdzono czy dane dają się dopasować do zakładanego modelu teoretycznego (określonych skal składających się z określonych pozycji). Miary dobroci dopasowania jakich użyto wraz z ich wynikami: (1) $\chi^{2} / \mathrm{df}=3,91$, dla poprawnego modelu miara przyjmuje wartość 3 i mniej, niektórzy badacze (Sagan, 2003) przyjmują, że akceptowalną wartością są te poniżej 5; (2) $\mathrm{GFI}=0,820$, indeks dobroci dopasowania (Goodness-of-Fit Index) - zawiera się w przedziale od 0 do 1 , im wyższa wartość tym lepsze dopasowanie; (3) PGFI = 0,609, oszczędny indeks dobroci dopasowania (Parsimony Goodness-of-Fit Index) - zawiera się w przedziale od 0 do 1 , im wyższa wartość tym lepsze dopasowanie; (4) PNFI $=0,747$, oszczędny unormowany indeks dopasowania (Parsimony Normed Fit Index) - zawiera się w przedziale od 0 do 1 , im wyższa wartość tym lepsze dopasowanie; (5) RMSEA = 0,135 (0,115-0,155), przedział ufności 90\%, pierwiastek średniokwadratowy błędu przybliżenia (Root Mean Square Error of Approximation) - zawiera się w przedziale od 0 do 1, dla poprawnego modelu miara przyjmuje wartości poniżej 0,08. Uzyskane wyniki nie pozwalają wnioskować o dopasowaniu danych do modelu (Sztemberg-Lewandowska, 
2008). Podsumowując wszystkie uzyskane wyniki należy stwierdzić, że warunki do spełnienia trafności teoretycznej PICART-Q są niewystarczające.

Postanowiono przeprowadzić eksploracyjną analizę czynnikową by sprawdzić w jakie czynniki można przekształcić zmienne i w jaki sposób będą one różne od oczekiwanych. Na podstawie macierzy korelacji, która wykazała istotne statystycznie korelacje między wszystkimi pozycjami, wykorzystano wszystkie zmienne (pozycje) do przeprowadzenia analizy czynnikowej. Przyjęto metodę i kryteria zastosowane przy tworzeniu brytyjskiej wersji kwestionariusza (CART-Q, Jowett i Ntoumanis, 2004): analizę głównych składowych (Principal Component Analysis, PCA) z wykorzystaniem rotacji ukośnej, która jest zalecana jeśli dopuszczamy korelację między czynnikami (Wieczorkowska i Wierzbiński, 2007). Kryteria, które wykorzystano do wyodrębniania czynników: (1) kryterium Kaisera - wartość własna czynnika większa niż 1 (co oznacza, że czynnik wyjaśnia więcej niż pojedyncza zmienna); (2) 5\% jako minimum wyjaśnionej wariancji dla jednego czynnika; (3) ładunki czynnikowe o wartości minimum 0,4 i przynajmniej 0,1 różnicy jeśli zmienna ładuje więcej niż jeden czynnik; oraz (4) akceptowalne wyniki testu sferyczności Bartletta i miary Kaisera-Meyera-Olkina adekwatności doboru (KMO, minimum 0,6$)$.

Analiza czynnikowa metodą głównych składowych wyodrębniła dwa czynniki, które spełniały wyżej wymienione kryteria. Pierwszy czynnik składa się z ośmiu pozycji, a drugi z trzech. Pozycja trzecia jako jedyna ma ładunek czynnikowy powyżej 0,4 dla obu czynników jednak różnica między ładunkami jest większa niż 0,1 , więc przypisano ją do czynnika drugiego. Otrzymane dzięki analizie dwa czynniki wyjaśniają 68,15\% wariancji zmiennych. Także czwarte kryterium zostało spełnione: $\mathrm{KMO}=0,917$, test sferyczności Bartletta istotny statystycznie $\chi^{2}(55, \mathrm{~N}=162)=1157,995 ; \mathrm{p}<0,001$, co potwierdza, że zmienne są ze sobą skorelowane i dane nadają się do wykonania analizy czynnikowej. Tabela 4 przedstawia macierz ładunków czynnikowych po rotacji ukośnej wraz z zasobami zmienności wspólnej po wyodrębnieniu czynników $\left(h^{2}\right)$ dla każdej pozycji; wartości procentowe wyjaśnionej wariancji dla czynników oraz ich wartości własne. Jak widać, że drugi czynnik ma wartość własną minimalnie przekraczającą przyjęte kryterium. 
Tabela 4. Eksploracyjna analiza czynnikowa - metoda głównych składowych (PCA)

\begin{tabular}{llll}
\hline \multirow{2}{*}{ Numer pozycji } & \multicolumn{2}{l}{ Czynnik } & \multicolumn{2}{l}{$h^{2}$} \\
\cline { 2 - 3 } $1(\mathrm{Z})$ & & 0,92 & 0,78 \\
$2(\mathrm{Z})$ & & 0,76 & 0,69 \\
$3(\mathrm{~B})$ & 0,42 & 0,59 & 0,72 \\
$4(\mathrm{~K})$ & 0,55 & & 0,56 \\
$5(\mathrm{~B})$ & 0,58 & & 0,69 \\
$6(\mathrm{Z})$ & 0,50 & & 0,60 \\
7 (K) & 0,76 & & 0,75 \\
$8(\mathrm{~B})$ & 0,82 & & 0,62 \\
$9(\mathrm{~B})$ & 0,80 & & 0,74 \\
$10(\mathrm{~K})$ & 0,89 & & 0,63 \\
$11(\mathrm{~K})$ & 0,78 & 9,56 & 0,72 \\
Procent wyjaśnionej wariancji & 58,60 & 1,05 & \\
Wartość własna & 6,45 & & \\
\hline W nawiasie obok numa pozycji & & & \\
\hline
\end{tabular}

W nawiasie obok numeru pozycji oznaczono zakładaną przynależność pozycji do konstruktu teoretycznego (B - bliskość, $\mathrm{Z}$ - zaangażowanie, $\mathrm{K}$ - komplementarność)

Aby obejrzeć jak zmienia się procent wyjaśnionej wariancji przez kolejne czynniki stworzono wykres osypiska (Rysunek 1). Jest to alternatywne kryterium dla wyodrębniania czynników, które zakłada, że ,jeśli wariancja kolejnych czynników jest zbliżona i już nie spada (małe nachylenie linii), możemy podjąć decyzję o ograniczeniu liczby czynników" (Wieczorkowska i Wierzbiński, 2007, s. 323). Decyzja jakie nachylenie linii jest wystarczająco małe by ograniczyć liczbę czynników należy do badacza. W tym przypadku nachylenie linii między drugą, a trzecią składową jest małe i biorąc pod uwagę fakt, że wartość własna czynnika drugiego przekracza przyjęte przez nas wcześniej kryterium Kaisera zaledwie o 0,05 zasadne wydaje się ograniczenie czynników do jednego. Wyodrębniony jeden czynnik jest odzwierciedleniem modelu zakładającego istnienie jednego, ogólnego konstruktu relacja trener-zawodnik, który brany był pod uwagę w analizach brytyjskiej i greckiej wersji kwestionariusza. 


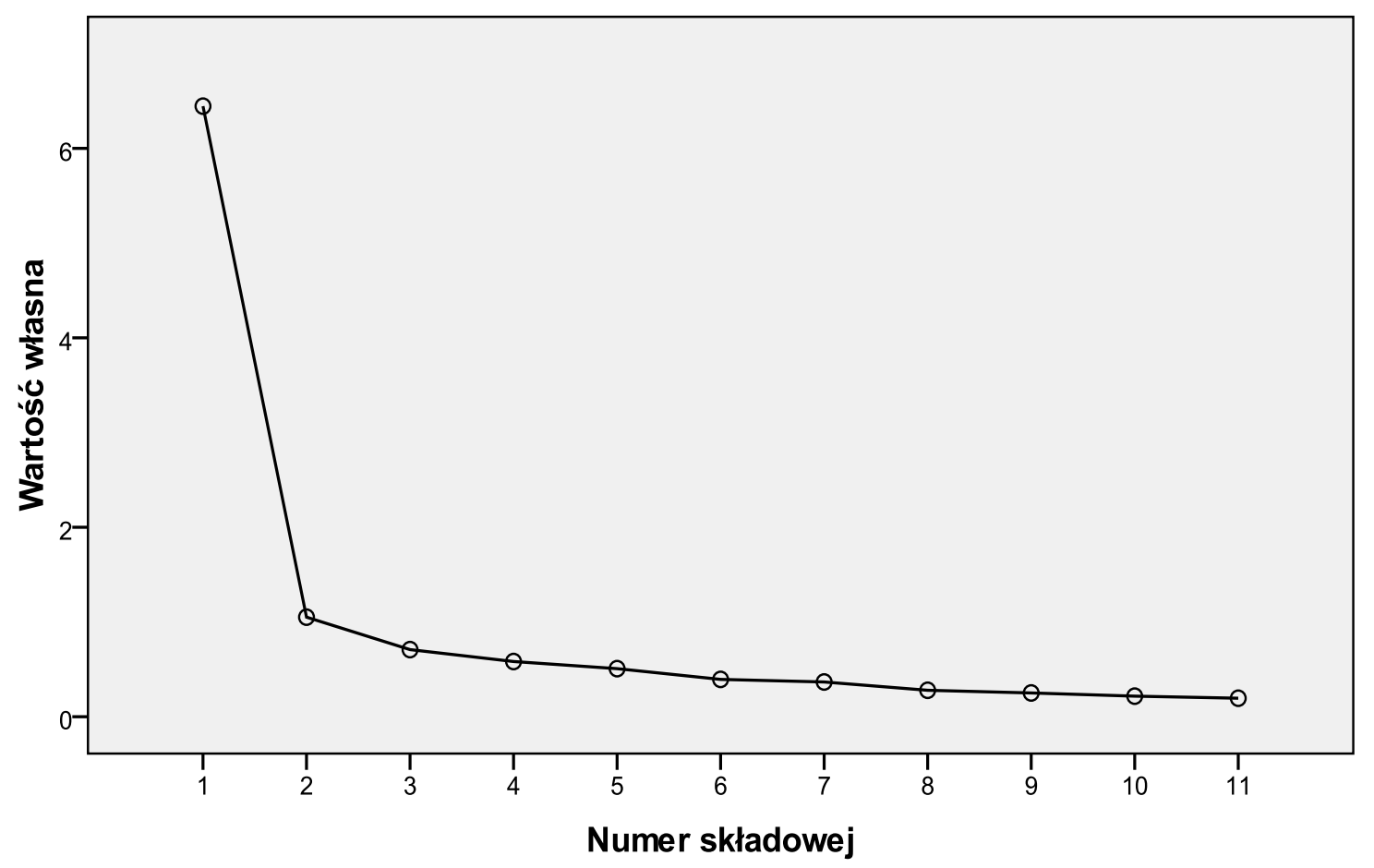

Rys 1 . Wykres osypiska.

\section{Dyskusja i zakończenie}

Analiza rzetelności oraz trafności kryterialnej kwestionariusza dała wyniki zadowalające. Nie została jednak potwierdzona trafność teoretyczna narzędzia, co sprawia, że rezultaty otrzymane w wyniku użycia takiego narzędzia są trudne do zinterpretowania (Brzeziński, 2005). W związku $\mathrm{z}$ powyższym, trafność kryterialna oraz rzetelność narzędzia mają znikome znaczenie. Kwestionariusz PICART-Q wymaga dalszych prac adaptacyjnych zanim będzie mógł być wykorzystywany do badania relacji trener-zawodnik.

Eksploracyjna analiza czynnikowa wykazała możliwość istnienia tylko jednego ogólnego czynnika relacja trener-zawodnik. Rzetelność oraz trafność kryterialna były także sprawdzane dla takiej alternatywy (wykorzystując wynik ogólny) i otrzymano wysokie wyniki. Przyjęcie założenia o istnieniu jednego konstruktu relacja-trener zawodnik jest jednak niewątpliwie ograniczeniem możliwości diagnostycznych tego narzędzia, bo nie mamy wglądu w poszczególne komponenty relacji. 
Należy jednak podkreślić, że, w przeciwieństwie do wersji brytyjskiej i greckiej, PICART-Q nie był tworzony od podstaw. W obu poprzednich przypadkach przeprowadzono eksploracyjną analizę czynnikową na danych zebranych $\mathrm{w}$ badaniu z użyciem pierwotnej skali składającej się z 25 pozycji. W wyniku tej analizy powstały dwa, różne kulturowo kwestionariusze. Miały one cechy wspólne - w obu wykazano istnienie trzech tych samych komponentów, ale różniły się pozycjami, które wchodziły w ich skład. Różnice te były interpretowane jako wynikające $\mathrm{z}$ wpływu kultury kolektywistycznej na zawodników i trenerów $\mathrm{z}$ Grecji, a indywidualistycznej na zawodników i trenerów brytyjskich. Potwierdza to hipotezy badaczy, że to w jakiej kulturze funkcjonuje związek trener-zawodnik ma wpływ na sposób interpretacji komponentów modelu 3C.

W niniejszej pracy nie powtórzono takiej samej procedury tworzenia kwestionariusza i jego walidacji, ale postanowiono skorzystać z istniejącej już wersji brytyjskiej. Jak sygnalizowano już wcześniej, taka procedura związana był z ryzykiem ujawnienia się różnic kulturowych, które mogłyby zaburzyć podstawy teoretyczne kwestionariusza. Warto kontynuować badania nad kwestionariuszem PICART-Q, ale zasadnym wydaje się przeprowadzenie procedury tworzenia kwestionariusza od początku czyli wychodząc od pierwotnej skali złożonej z 25 pozycji. Możliwe, że inne pozycje będą wchodziły w skład kwestionariusza, ale uda się zachować jego trójczynnikowy, zgodny z modelem 3C, charakter.

\section{Literatura cytowana}

Brzeziński, J. (red.). (2005). Trafność i rzetelność testów psychologicznych. Wybór tekstów. Gdańsk: Gdańskie Wydawnictwo Psychologiczne.

Drwal, R. Ł. (1995). Adaptacja kwestionariuszy osobowości. Wybrane zagadnienia i techniki.

Warszawa: Wydawnictwo Naukowe PWN.

Hofstede, G. i Hofstede, G. J. (2005). Cultures and organizations - Software of the mind. New York: McGraw-Hill.

Jowett, S. (2003). When the „Honeymoon” is over: A case study of a coach-athlete dyad in crisis. The Sport Psychologist, 17, 444-460.

Jowett, S. i Cockerill, I. M. (2003). Olympic Medallists' perspective of the athlete-coach relationship. Psychology of Sport and Exercise, 4, 313-331.

Jowett, S. i Meek, G.A. (2000). The coach-athlete relationships in married couples: An exploratory content analysis. The Sport Psychologist, 14, 157-175. 
Jowett, S. i Ntoumanis, N. (2003). The Greek Coach-Athlete Relationship Questionnaire (GrCARTQ): Scale development and validation. International Journal of Sport Psychology, 34, 101-124.

Jowett, S. i Ntoumanis, N. (2004). The coach-athlete relationship questionnaire (CART-Q):

Development and initial validation. Scandinavian Journal of Medicine and Science in Sports, $14,245-257$.

Nunnally, J. C i Bernstein I. H. (1994). Psychometric theory, 3rd edn. New York: McGraw- Hill.

Poczwardowski, A., Barott, J. A. i Jowett, S. (2006). Diversifying approaches to research on athlete-coach relationships. Psychology of Sport and Exercise, 7, 125-142.

Sagan, A. (2003). Model pomiarowy satysfakcji i lojalności. StatSoft Polska.

Sztemberg-Lewandowska, M. (2008). Analiza Czynnikowa w badaniach marketingowych. Wrocław: Wydawnictwo Uniwersytetu Ekonomicznego we Wrocławiu.

Wieczorkowska, G. i Wierzbiński, J. (2007). Statystyka. Analiza badań społecznych. Warszawa: Wydawnictwo Naukowe SHOLAR. 
Załącznik 1. PICART-Q (obie wersje: dla trenera i zawodnika)

\section{Kwestionariusz do badania relacji trener-zawodnik (PICART-Q): ZAWODNIK}

Kwestionariusz ten ma na celu zbadanie jakości i elementów składowych relacji trener-zawodnik. Proszę o uważne przeczytanie poniższych stwierdzeń i podjęcie decyzji na ile się Pan (Pani) z nimi zgadza lub nie. Żadna z odpowiedzi nie jest dobra lub zła. Proszę o szczere odpowiedzi, odpowiadające Pana (Pani) osobistym odczuciom względem trenera. Wybrane odpowiedzi proszę zaznaczyć kółkiem.

Zdecydowanie Umiarkowanie Zdecydowanie

1. Mój trener jest bliską mi osobą.

$\begin{array}{lllllll}1 & 2 & 3 & 4 & 5 & 6 & 7 \\ 1 & 2 & 3 & 4 & 5 & 6 & 7\end{array}$

2. Jestem zaangażowany $w$ relację $z$ moim trenerem.

$\begin{array}{lllllllll}\text { 3. Lubię mojego trenera. } & 1 & 2 & 3 & 4 & 5 & 6 & 7 \\ \begin{array}{l}\text { 4. Czuję się swobodnie, kiedy trenuję z moim } \\ \text { trenerem. }\end{array} & 1 & 2 & 3 & 4 & 5 & 6 & 7\end{array}$

5. Ufam mojemu trenerowi.

$\begin{array}{lllllll}1 & 2 & 3 & 4 & 5 & 6 & 7\end{array}$

$\begin{array}{llllllllll}\text { 6. Czuję, że pod opieką mojego trenera moja kariera } & 1 & 2 & 3 & 4 & 5 & 6 & 7\end{array}$ sportowa jest obiecująca.

$\begin{array}{lllllllllll}\text { 7. Kiedy trenuję } \mathrm{z} \text { moim trenerem, reaguję na jego } & 1 & 2 & 3 & 4 & 5 & 6 & 7\end{array}$ starania.

8. Szanuję mojego trenera.

$\begin{array}{lllllll}1 & 2 & 3 & 4 & 5 & 6 & 7\end{array}$

$\begin{array}{lllllllllll}\text { 9. Doceniam poświęcenia mojego trenera mające } & 1 & 2 & 3 & 4 & 5 & 6 & 7\end{array}$ służyć doskonaleniu osiągnięć.

10.Kiedy trenuję z moim trenerem, jestem gotowy $\quad \begin{array}{lllllllllll}1 & 2 & 3 & 4 & 5 & 6 & 7\end{array}$ dać $z$ siebie wszystko.

11.Kiedy trenuję z moim trenerem, jestem przyjaźnie $\begin{array}{llllllllll}1 & 2 & 3 & 4 & 5 & 6 & 7\end{array}$ nastawiony.

Nie jestem wcale Umiarkowanie Jestem zupełnie usatysfakcjonowany usatysfakcjonowany

$\begin{array}{lllllllll}\begin{array}{l}\text { 12.Czy ogólnie jesteś usatysfakcjonowany swoją } \\ \text { relacją z trenerem? }\end{array} & 1 & 2 & 3 & 4 & 5 & 6 & 7 \\ \begin{array}{l}\text { 13.Czy uważasz, że Twój trener jest ogólnie } \\ \text { usatysfakcjonowany Waszą relacją? }\end{array} & 1 & 2 & 3 & 4 & 5 & 6 & 7\end{array}$




\section{Kwestionariusz do badania relacji trener-zawodnik (PICART-Q): TRENER}

Kwestionariusz ten ma na celu zbadanie jakości i elementów składowych relacji trener-zawodnik. W tej części proszę o uważne przeczytanie poniższych stwierdzeń i podjęcie decyzji na ile się Pan (Pani) z nimi zgadza lub nie. Żadna z odpowiedzi nie jest dobra lub zła. Proszę o szczere odpowiedzi, odpowiadające Pana (Pani) osobistym odczuciom względem jednego, wybranego zawodnika, z którym Pan (Pani) pracuje. Wybrane odpowiedzi proszę zaznaczyć kółkiem.

\begin{tabular}{|c|c|c|c|c|c|c|c|}
\hline \multirow[b]{2}{*}{ 1. Mój zawodnik jest bliską mi osobą. } & \multicolumn{2}{|c|}{ Zdecydowanie } & \multicolumn{3}{|c|}{ Umiarkowanie } & \multicolumn{2}{|c|}{ Zdecydowanie } \\
\hline & 1 & 2 & 3 & 4 & 5 & 6 & 7 \\
\hline $\begin{array}{l}\text { 2. Jestem zaangażowany w relację z moim } \\
\text { zawodnikiem. }\end{array}$ & 1 & 2 & 3 & 4 & 5 & 6 & 7 \\
\hline 3. Lubię mojego zawodnika. & 1 & 2 & 3 & 4 & 5 & 6 & 7 \\
\hline $\begin{array}{l}\text { 4. Czuję się swobodnie, kiedy trenuję mojego } \\
\text { zawodnika. }\end{array}$ & 1 & 2 & 3 & 4 & 5 & 6 & 7 \\
\hline 5. Ufam mojemu zawodnikowi. & 1 & 2 & 3 & 4 & 5 & 6 & 7 \\
\hline $\begin{array}{l}\text { 6. Czuję, że pracując z moim zawodnikiem, moja } \\
\text { kariera trenerska jest obiecująca. }\end{array}$ & 1 & 2 & 3 & 4 & 5 & 6 & 7 \\
\hline $\begin{array}{l}\text { 7. Kiedy trenuję mojego zawodnika, reaguję na jego } \\
\text { starania. }\end{array}$ & 1 & 2 & 3 & 4 & 5 & 6 & 7 \\
\hline 8. Szanuję mojego zawodnika. & 1 & 2 & 3 & 4 & 5 & 6 & 7 \\
\hline $\begin{array}{l}\text { 9. Doceniam poświęcenia mojego zawodnika } \\
\text { mające służyć doskonaleniu osiągnięć. }\end{array}$ & 1 & 2 & 3 & 4 & 5 & 6 & 7 \\
\hline $\begin{array}{l}\text { 10.Kiedy trenuję mojego zawodnika, jestem gotowy } \\
\text { dać z siebie wszystko. }\end{array}$ & 1 & 2 & 3 & 4 & 5 & 6 & 7 \\
\hline $\begin{array}{l}\text { 11. Kiedy trenuję mojego zawodnika, jestem } \\
\text { przyjaźnie nastawiony. }\end{array}$ & 1 & 2 & 3 & 4 & 5 & 6 & 7 \\
\hline
\end{tabular}

$\begin{array}{ccc}\text { Nie jestem wcale } & \text { Umiarkowanie } & \begin{array}{c}\text { Jestem zupełnie } \\ \text { usatysfakcjonowany }\end{array} \\ \text { usatysfakcjonowany }\end{array}$

12.Czy ogólnie jesteś usatysfakcjonowany swoją relacją z zawodnikiem?

13. Czy uważasz, że Twój zawodnik jest ogólnie usatysfakcjonowany Waszą relacją? $\begin{array}{lllllll}1 & 2 & 3 & 4 & 5 & 6 & 7\end{array}$

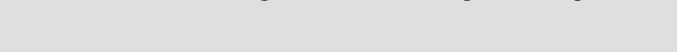

$\begin{array}{lllllll}1 & 2 & 3 & 4 & 5 & 6 & 7\end{array}$

